\title{
WATER SENSITIVE URBAN DESIGN AND STORMWATER HARVESTING - ON THE PATH TO SUSTAINABLE URBAN DEVELOPMENT - CASE STUDIES FROM SYDNEY, AUSTRALIA
}

\author{
Olof J. Jonasson ${ }^{I}$ \\ Peter Davies ${ }^{2}$ \\ 'Environmental Engineer, Ku-ring-gai Council, NSW, Australia \\ ${ }^{2}$ Manager Sustainability, Ku-ring-gai Council, NSW, Australia
}

\begin{abstract}
In Australia, Water Sensitive Urban Design (WSUD) or Sustainable Urban Drainage (SUDS) is being used to integrate urban drainage and water supply infrastructure planning and design with elements of hydrology, ecology, land use planning and landscaping. To support this direction, various National and State guidelines and legislation have been developed that are aimed at changing traditional engineering and urban design practice.
\end{abstract}

Recent droughts affecting most of Eastern Australia, including three capital cities, has led to a focus on urban water management. This has increased the attention and recognition of integrated water management including water conservation, demand management, diversification of supply, protecting environmental flows and improving water quality at the receiving bodies. Within Australia, stormwater reuse is being promoted as one way to lessen the demand on drinking water supplies for non-potable uses. Important for urban areas is the need for appropriate levels of treatment (depending on use) and sufficient storage to provide a reliable supply. From an integrated water management perspective such projects can have multiple benefits through managing the discharge and improving the quality from low frequent storms at the local scale while providing broader water conservation gains across the urban area.

This paper discusses two case studies from Australia that have applied integrated water management principles within an existing urban catchment. These include a stormwater harvesting project to irrigate a sports field and a car park bioretention system to treat road runoff before it discharges to a natural stream.

\section{KEYWORDS}

Water Sensitive Urban Design; Integrated water management; Stormwater harvesting; Stormwater treatment.

\section{INTRODUCTION}

Ku-ring-gai local government area (LGA) is located approximately $15 \mathrm{~km}$ north of the Sydney CBD in New South Wales, Australia. The LGA covers an area of $85.4 \mathrm{~km}^{2}[1]$ and is characterised by low density residential housing set on individual lots. The population is 
approximately 101,000 [2]. The landscape is characterised by low density urban development located on the flatter ridge tops with the steeper slopes to the three major catchments comprised of bushland much of which is within National Park estate. The annual rainfall is approximately $1,430 \mathrm{~mm}$ per year [3].

Urban areas continue to impact on natural systems. Stormwater runoff contains a range of pollutants such as litters, sediments, metals and nutrients. Changes to the hydraulics, physical, chemical and biological conditions of receiving water bodies are also experienced due to the increase in impervious areas and construction of engineered drainage networks $[4,5,6]$. Across the Ku-ring-gai LGA this has been measured across water chemistry, biology and hydrology studies [7].

Integrated water management or water sensitive urban design (WSUD) seeks to address these changes through recognising the relationships of urban drainage and water supply infrastructure planning with design elements of hydrology, ecology, land use planning and landscaping [8]. Supporting this approach has been a range of government polices, guidelines and in some states legislation that have drawn from research, case studies and pilots undertaken by various institutions and land managers $[8,9,10,11,12,13,14,15,16]$.

For local government in Australia, WSUD is still an emerging path. Within Sydney, references is made to this through various government policies such as the 2006 Metropolitan Water Plan [17] that identifies and promotes various water recycling and reuse projects. However, for local government, the ability to introduce these projects is often left to the motivation of individual officers and Councils and all too often turns on opportunistic projects, trials or demonstration sites as a means to progress better stormwater and whole or water cycle management. While stormwater reuse scheme are promoted as good practice [13] their design and performance are not subject to minimum mandatory health standards as are water recycling plants that may leave local councils and others in a precarious legal position in the future [18].

Ku-ring-gai Council is currently implementing a water management program that will see 12 stormwater harvesting system being built in the next five years, with an estimated saving of approximately $36 \mathrm{ML}$ of potable water per year. In addition, the Council is also committed to constructing a sewer mining facility to irrigate open space areas as well as implementing various water sensitive urban design features across our developed landscape.

\subsection{Water quality requirements}

The NSW Department of Environment and Conservation [13] has published a guideline on stormwater harvesting and reuse. This is mostly concerned with public health, relying on faecal coliforms as an indicator of the suitability of water for indirect human contact, and in the case of performance of irrigation infrastructure nutrients and suspended solid loads. In part the use of guidelines rather than mandatory standards or laws reflects the high variability of stormwater quality and may impact on the cost of treatment for reuse projects. Importantly however, it has been recognized that a "fit for purpose" ethos acknowledges that it is not necessary to have potable standard water for all applications. 
Table I. NSW Department of Environment and Conservation's guidelines, stormwater quality criteria for public health risk management for stormwater reuse [13].

\begin{tabular}{|c|c|c|}
\hline Level & Criteria (1) & Applications \\
\hline \multirow[b]{4}{*}{ Level 1} & E. coli $<1 \mathrm{cfu} / 100 \mathrm{~mL}$ & \multirow[b]{4}{*}{$\begin{array}{l}\text { Reticulated non-potable residential uses (e.g. garden } \\
\text { watering, toilet flushing, car washing) }\end{array}$} \\
\hline & Turbidity $\leq 2$ NTU (2) & \\
\hline & $\mathrm{pH} 6.5-8.5$ & \\
\hline & $\begin{array}{l}1 \mathrm{mg} / \mathrm{LCl}_{2} \text { residual after } 30 \\
\text { minutes or equivalent level of } \\
\text { pathogen reduction }\end{array}$ & \\
\hline \multirow[b]{4}{*}{ Level 2} & E. coli $<10 \mathrm{cfu} / 100 \mathrm{~mL}$ & \multirow{2}{*}{$\begin{array}{l}\text { Spray or drip irrigation of open spaces, parks and } \\
\text { sportsgrounds (no access controls) Industrial uses - } \\
\text { dust suppression, construction site use (human } \\
\text { exposure possible) }\end{array}$} \\
\hline & Turbidity $\leq 2$ NTU2 & \\
\hline & $\mathrm{pH} 6.5-8.5$ & Ornamental water bodies (no access controls) \\
\hline & $\begin{array}{l}1 \mathrm{mg} / \mathrm{LCl}_{2} \text { residual after } 30 \\
\text { minutes or equivalent level of } \\
\text { pathogen reduction }\end{array}$ & Fire-fighting \\
\hline \multirow{3}{*}{ Level 3} & E. coli $<1000 \mathrm{cfu} / 100 \mathrm{~mL}$ & $\begin{array}{l}\text { Spray or drip irrigation (controlled access) or } \\
\text { subsurface irrigation of open spaces, parks and } \\
\text { sportsgrounds }\end{array}$ \\
\hline & pH 6.5-8.5 & $\begin{array}{l}\text { Industrial uses - dust suppression, construction site } \\
\text { use, process water (no human exposure) }\end{array}$ \\
\hline & & Ornamental water bodies (access controls) \\
\hline
\end{tabular}

This paper discusses two case studies within the Ku-ring-gai Council LGA that have applied sustainable urban development principles in retrofit situations. These include a sports field stormwater harvesting irrigation scheme and a car park bioretention system to treat road runoff. Each project has considered a range of factors in its design including the local importance of the receiving water bodies, proximity and value of adjacent bushland, social and community benefits need to improve water quality and manage runoff volumes.

\section{CASE STUDY 1: SPORTSFIELD STORWMATER HARVESTING IRRIGATION SCHEME}

The sports field irrigation scheme described in this case study is located at Edenborough sportsfield, Lindfield NSW (Latitude 33:46:59, Longitude 151:09:43). The field is mainly used for soccer in winter and cricket in summer. It is also used for archery and as a dog offleash area all year around. The field is currently not irrigated.

Due to the popularity of sport especially soccer, demand and consequent wear is beyond what is sustainable in terms of providing a sound playing surface. Reconstruction of the oval soil profile and providing irrigation are two mechanisms that can improve its condition and longevity. Water restrictions imposed by the State Government as a consequence of a longer term drought affecting much of Eastern Australia, limits the use of potable supplies for irrigating open space areas so therefore a more sustainable source of water must be found if the social and community benefit of this asset is to be continually realized. 
As part of the identification of this site for its suitability for a stormwater reuse project, the catchment and site was assessed and a water balance model was built. These factors were used to evaluate levels of water security from a supply and demand perspective in response to differential storage volumes and historical rainfall characteristics. Modelling was conducted using a water balance model developed by Ku-ring-gai Council that incorporated 64 years of daily rainfall data from Turramurra (Australian Bureau of Meteorology site 066158 located approximately $3 \mathrm{~km}$ from the site) between 1936 and 2000. The model incorporated soil water holding capacity and losses from storage through evaporation (standard daily evapotranspiration data for Sydney Observatory Hill, located approximately $14 \mathrm{~km}$ from the site) and deep soil infiltration to determine irrigation demand. Impacts on modeling outcomes as a result of limitations in pipe capacity, weir heights, treatment capacity of water quality devices, pump capacity and other design factors were not considered as part of the initial assessment. Above ground irrigation system (sprinklers) was assumed for all irrigation scenarios.

After this initial investigation and modeling it was determined that the harvesting system would best operated by collecting stormwater runoff from only a portion of the upstream catchment that could drain by gravity to the proposed storage location. Whilst this reduced the potential supply, through collecting runoff from a smaller catchment, advantages were realized via a simpler design, reduced cost, elimination of pumps and lower longer term maintenance. All designs and investigation was done in-house by Council staff.

Total storage was sized at $310 \mathrm{~kL}$ in two $155 \mathrm{~kL}$ concrete storage tanks located adjacent to the playing field. This provided an estimated security of water supply of $70 \%$ by volume, providing about $2,000 \mathrm{~kL}$ of reused water per year. The tanks were design to have a viewing platform for spectators on top and a soccer practice rebound wall in front.

\subsection{Water quality treatment}

The upstream catchment covers about three hectares of residential areas. Of the three hectares, approximately 1 hectare is roads and other hard surfaces that are connected to the drainage system. Stormwater is diverted from an existing stormwater line and is passes through a $5 \mathrm{~mm}$ mesh screen designed to capture litter and large sediments. The water is then conveyed to the sand filter. A sand filter was incorporated into the design for its good ability to remove fine sediments and faecal coliforms from stormwater [19].

Stormwater is distributed into the filter through an internal slotted pipe, with some perculation also occurring through the surface of the filter. A schematic of the filter is shown in Figure 1. Depending on the rainfall intensity, excess volumes will pond on top of the filter before bypassing the filter through a surcharge pit and into the storage tanks. The bypass pit is equipped with a 100 micron pit litter basket.

The sand filter is designed to treat the first $5-10 \mathrm{~mm}$ of stormwater runoff on the assumption that the initial flow or "first flush" is more likely to carry a higher concentration of pollutants than successive flows [20]. Once in the storage tanks, further sedimentation of fine sediment not captured in the sand filter will occur. 


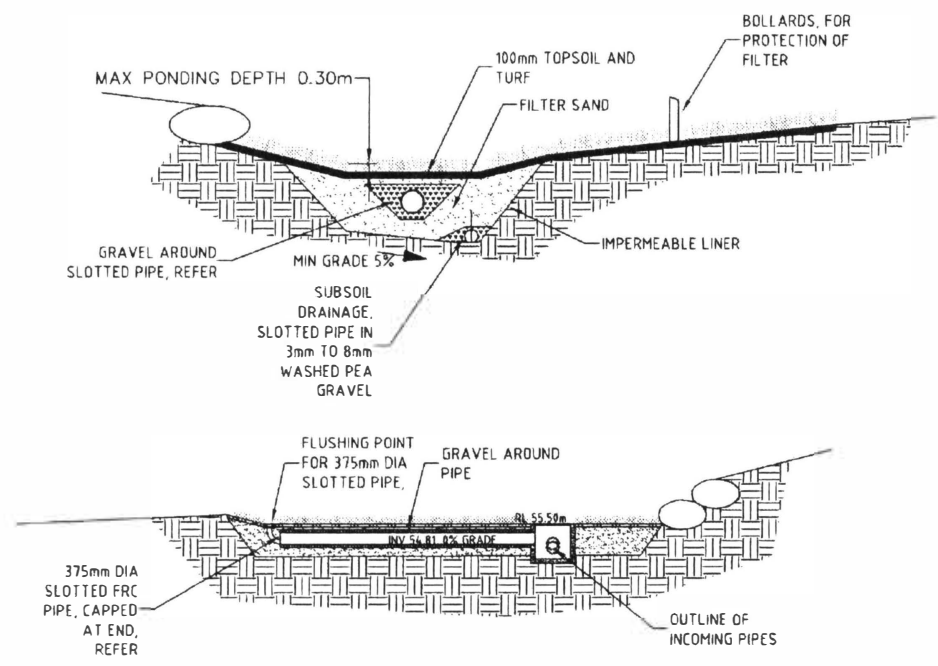

Figure 1. Sand filter schematics.

\subsection{Expected water quality}

The expected water quality performance of the system was assessed using the Model for Urban Stormwater Improvement Conceptualisation (MUSIC) as developed by the Australian Cooperative Research Centre for Catchment Hydrology. This computer model can assess the likely water quality improvements that can be expected from different stormwater quality improvement strategies [21].

For the litter screen, it was assumed that $80 \%$ of gross pollutants (pollutants that is retained by a $5 \mathrm{~mm}$ screen) would be captured, with no reduction in nutrients or suspended solids. For sand filters or bioretention systems (as similarly defined by MUSIC) and the storage tanks, standard treatment nodes as provided in MUSIC were used. It is recognized that the bioretention systems as modeled in the MUStC program assumes more vegetation and biological activity than what can be expected in a sand filter. A high hydraulic conductivity ( $360 \mathrm{~mm} /$ hour) was therefore chosen to reflect the sand filter medium. The MUSIC model used 6 minutes rainfall data from 1959 (Sydney Observatory Hill), with a mean annual rainfall of $1490 \mathrm{~mm} /$ year. The overall imperviousness of the catchment was assumed to be $30 \%$.

The predicted runoff and pollutant quantities are presented in Table 2. The predicted water quality improvement for each of the treatment measures as part of the stormwater harvesting system is presented in Table 3. It should be noted that the water quality modeling does not include reuse of the harvested water. Reuse of harvested water will further reduce the load of nutrients and fine sediments to the receiving waters. Notable in this modeling is that faecal coliforms, indicator of the presence of Escherichia coli, is not modeled due to its extreme variability across catchments and storm flows [22]. 
Table 2. Predicted runoff and pollutant quantities.

\begin{tabular}{|c|c|c|}
\hline Total catchment & Flow (ML/yr) & 17 \\
\hline \multirow{4}{*}{} & Total Suspended Solids (kg/yr) & 2.700 \\
\cline { 2 - 3 } & Total Phosphorus (kg/yr) & 6.04 \\
\cline { 2 - 3 } & Total Nitrogen $(\mathrm{kg} / \mathrm{yr})$ & 44.8 \\
\cline { 2 - 3 } & Gross Pollutants $(\mathrm{kg} / \mathrm{yr})$ & 460 \\
\hline Diverted to harvesting system & Flow (ML/yr) & 12.2 \\
\hline \multirow{5}{*}{ Bypass harvesting system } & Total Suspended Solids (kg/yr) & 1.930 \\
\cline { 2 - 3 } & Total Phosphorus (kg/yr) & 4.32 \\
\cline { 2 - 3 } & Total Nitrogen $(\mathrm{kg} / \mathrm{yr})$ & 32.1 \\
\cline { 2 - 3 } & Gross Pollutants $(\mathrm{kg} / \mathrm{yr})$ & 400 \\
\hline & Flow $(\mathrm{ML} / \mathrm{yr})$ & 4.8 \\
\hline & Total Suspended Solids $(\mathrm{kg} / \mathrm{yr})$ & 767 \\
\cline { 2 - 3 } & Total Phosphorus $(\mathrm{kg} / \mathrm{yr})$ & 1.72 \\
\cline { 2 - 3 } & Total Nitrogen $(\mathrm{kg} / \mathrm{yr})$ & 12.7 \\
\cline { 2 - 3 } & Gross Pollutants $(\mathrm{kg} / \mathrm{yr})$ & 59.8 \\
\hline
\end{tabular}

Table 3. Predicted water quality improvement for each of the treatment measures.

\begin{tabular}{|c|c|c|c|}
\hline Litter screen & Inflow & Outflow & Reduction \\
\hline Flow (ML/yr) & 12.2 & 12.2 & $0 \%$ \\
\hline Total Suspended Solids (kg/yr) & 1930 & 1930 & $0 \%$ \\
\hline Total Phosphorus (kg/yr) & 4.32 & 4.32 & $0 \%$ \\
\hline Total Nitrogen (kg/yr) & 32.1 & 32.1 & $0 \%$ \\
\hline Gross Pollutants (kg/yr) & 400 & 80 & $80 \%$ \\
\hline Sand filter & Inflow & Outflow & Reduction \\
\hline Flow (ML/yr) & 12.2 & 12.2 & $0 \%$ \\
\hline Total Suspended Solids (kg/yr) & 1930 & 601 & $69 \%$ \\
\hline Total Phosphorus (kg/yr) & 4.32 & 1.99 & $54 \%$ \\
\hline Total Nitrogen (kg/yr) & 32.1 & 22.9 & $29 \%$ \\
\hline Gross Pollutants (kg/yr) & 80 & 0 & $100 \%$ \\
\hline Storage tanks & Inflow & Outflow & Reduction \\
\hline Flow (ML/yr) & 12.2 & 12.2 & $0 \%$ \\
\hline Total Suspended Solids (kg/yr) & 601 & 393 & $35 \%$ \\
\hline Total Phosphorus (kg/yr) & 1.99 & 1.94 & $3 \%$ \\
\hline Total Nitrogen (kg/yr) & 22.9 & 21 & $8 \%$ \\
\hline Gross Pollutants (kg/yr) & 0 & 0 & $0 \%$ \\
\hline Total reduction, diverted flow & Inflow & Outflow & Reduction \\
\hline Flow (ML/yr) & 12.2 & 12.2 & $0 \%$ \\
\hline Total Suspended Solids (kg/yr) & 1930 & 393 & $80 \%$ \\
\hline Total Phosphorus (kg/yr) & 4.32 & 1.94 & $55 \%$ \\
\hline Total Nitrogen (kg/yr) & 32.1 & 21 & $35 \%$ \\
\hline Gross Pollutants (kg/yr) & 400 & 0 & $100 \%$ \\
\hline Total reduction from catchment & Inflow & Outflow & Reduction \\
\hline Flow (ML/yr) & 17 & 17 & $0 \%$ \\
\hline Total Suspended Solids (kg/yr) & 2700 & 1160 & $57 \%$ \\
\hline Total Phosphorus (kg/yr) & 6.04 & 3.66 & $39 \%$ \\
\hline Total Nitrogen (kg/yr) & 44.8 & 33.7 & $25 \%$ \\
\hline Gross Pollutants (kg/yr) & 460 & 59.8 & $87 \%$ \\
\hline
\end{tabular}


For stormwater reuse projects the quality of water affecting plants (turf) and irrigation system is a significant design and operational issue. For irrigating of sports facilities, suspended solids levels below $50 \mathrm{mg} / \mathrm{L}$ are unlikely to result in operational problems with the irrigation infrastructure in so far as blocking irrigation systems [13]. High concentrations of nutrients can lead to a build up of bio-films that may cause clogging of irrigation and affect plant health. Long-term (100 years) and short-term (20 years) maximum recommended concentrations of TN and TP in irrigation water are presented in Table 4. The predicted concentrations of TN, TP and TSS (leaving the storage tank) are presented as cumulative frequency graphs (flow weighted daily mean) in Figures 2-4. These show the harvested stormwater at Edenborough sportsfield is not predicted to cause any problems to the irrigation infrastructure in the short (20 year) term, but should be monitored for long term performance.

Table 4. Maximum recommended concentrations of TN, TP [13].

\begin{tabular}{|l|c|c|}
\hline Element & Long term (up to 100 years) & Short term (up to 20 years) \\
\hline Total phosphorus $(\mathrm{mg} / \mathrm{L})$ & 0.05 & $0.8-12^{*}$ \\
\hline Total nitrogen $(\mathrm{mg} / \mathrm{L})$ & 5 & $25.0-125^{*}$ \\
\hline
\end{tabular}

* Requires site-specific assessment (refer to ANZECC \& ARMCANZ 2000 [22])

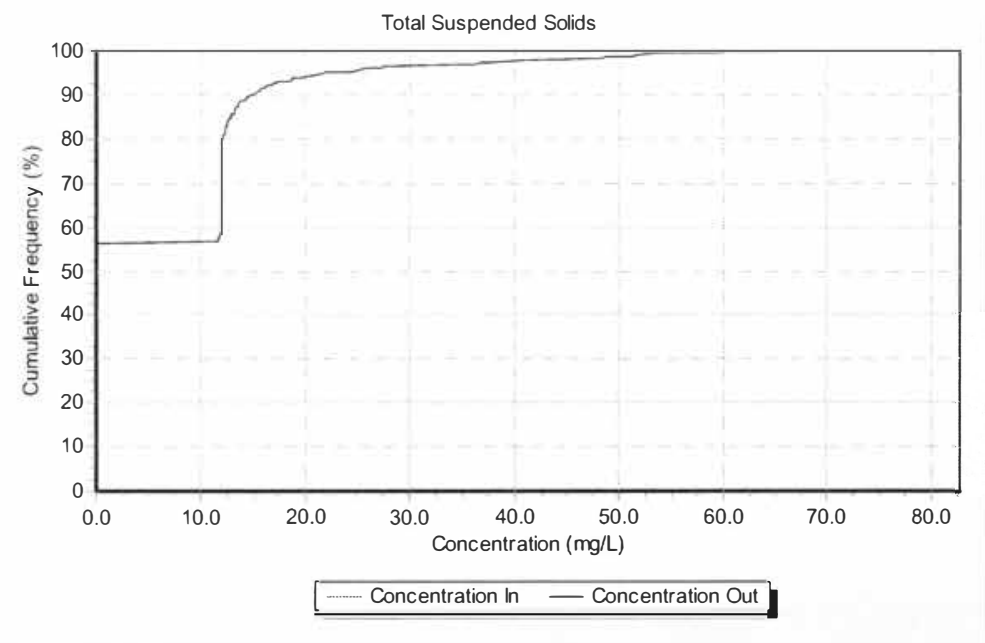

Figure 2. Cumulative frequency graphs (flow' weighted daily mean), TSS. 
Kalmar ECO-TECH '07

KALMAR, SWEDEN, November 26-28, 2007

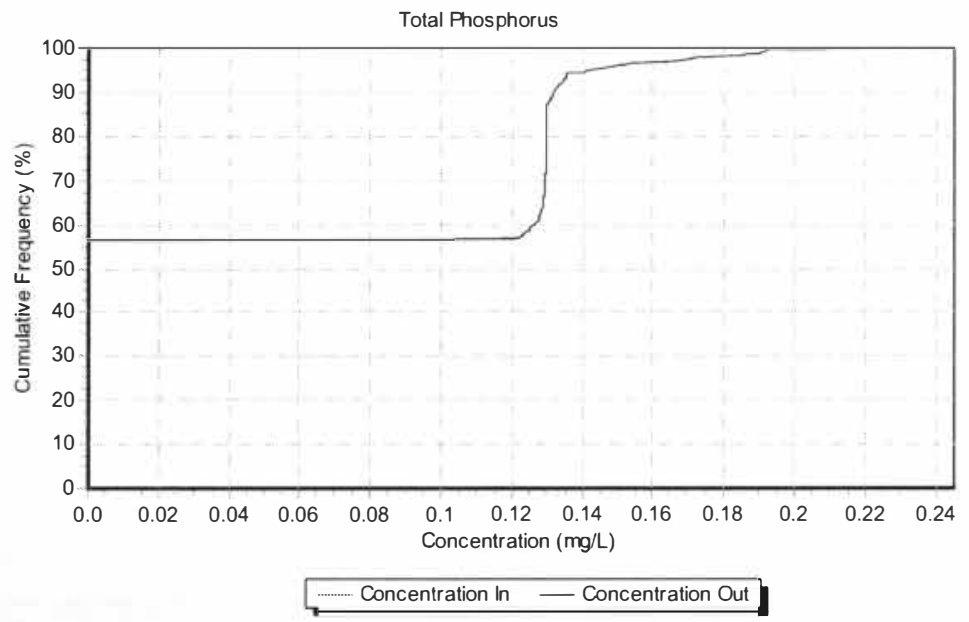

Figure 3. Cumulative frequency graphs (flow' weighted daily mean), TP.

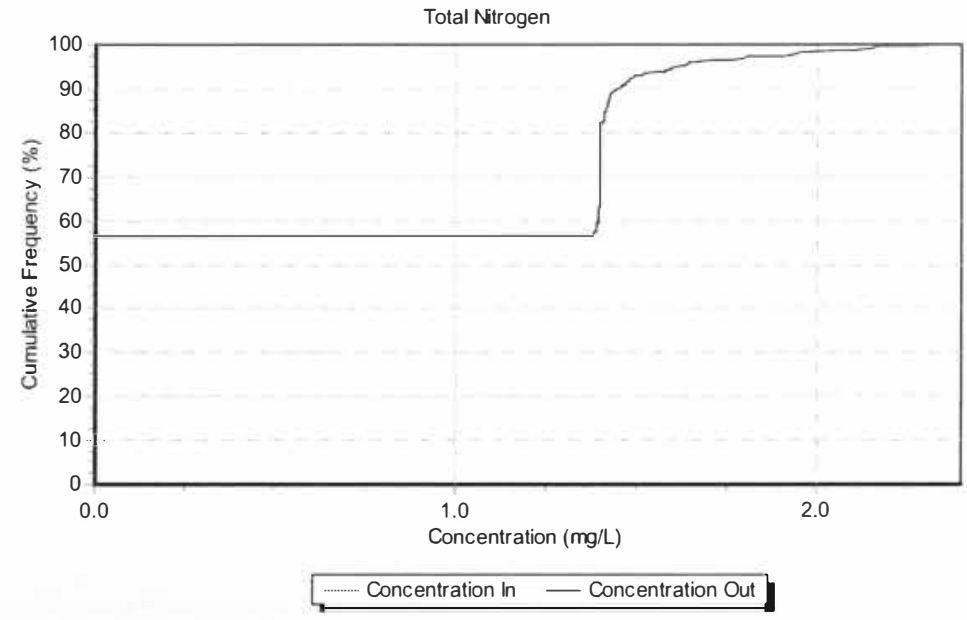

Figure 4 Cumulative frequency graphs (flow weighted daily mean), TN

\section{CASE STUDY 2: BIORETENTION SYSTEM FOR TREATING STORMWATER RUNOFF FROM ROAD SURFACE}

The sports ground car park bioretention system described in this case study is located adjacent to Turramurra Memorial Oval, Turramurra (Latitude 33:43:35, Longitude 151:07:49). The carpark is located immediately upstream of Lovers Jump Creek, that discharges into the 
Hawkesbury River. A litter screen was installed within the creek in 2004 that captures gross pollutants such as leaves, bottles and food wrappers.

The bioretention systems were designed to reduce pollutants entering Lovers Jump Creek and in the longer term contribute to a stormwater harvesting project to irrigate the oval and surrounds. Three bioretention pits were installed. Two contained a sandy loam soil mix and their third incorporated soil conditioned with recycled organics. Ongoing monitoring will seek to evaluate the effectiveness of this media against the engineered soil to absorb various pollutants such as metals and hydrocarbons. Three individual bioretention gardens were designed to treat approximately $95 \%$ of the average annual runoff by volume with a catchment area of approximately $1,000 \mathrm{~m}^{2}$.

\subsection{Water quality treatment}

Each garden was designed to complement the existing stormwater quality measure (litter screen) and targets pollutants that the litter screen is not able to capture. This includes sediments, and dissolved pollutants such as nutrients and metals. The individual gardens were equipped with a grated inlet that effectively separates leaves and litter from entering the bioretention gardens. The litter is captured by the litter screen downstream or by street sweepers. Water is designed to pond in the gardens to a depth of $300 \mathrm{~mm}$, allowing a significant percentage of the runoff to be treated by the gardens.

\subsection{Expected water quality}

The expected water quality performance of the system was assessed using MUSIC [21]. Standard treatment nodes as provided in MUSIC were used for the bioretention systems, with a hydraulic conductivity chosen to reflect the sandy soil used as the filter medium. The MUSIC model used 6 minutes rainfall data from 1959 (Sydney Observatory Hill), with a mean annual rainfall of $1490 \mathrm{~mm} /$ year. The overall imperviousness of the catchment was set to $100 \%$.

The predicted runoff and pollutant quantities are presented in Table 5.

Table 5. Predicted water quality improvement for carpark bioretention system.

\begin{tabular}{|c|c|c|c|}
\hline Bio retention gardens & Inflow & Outflow & Reduction \\
\hline Flow (ML/yr) & 1.31 & 1.31 & $0 \%$ \\
\hline Total Suspended Solids (kg/yr) & 207 & 15.5 & $93 \%$ \\
\hline Total Phosphorus (kg/yr) & 0.464 & 0.104 & $78 \%$ \\
\hline Total Nitrogen (kg/yr) & 3.44 & 1.57 & $54 \%$ \\
\hline Gross Polbutants (kg/yr) & 31.7 & 31.7 & $0 \%$ \\
\hline
\end{tabular}

\section{CONCLUSIONS}

The case studies presented in this paper show examples of WSUD in practice within a retrofit situation. The effieacy of these projects is yet to be validated against the modeling outcomes. Monitoring will be undertaken during rainfall within the catchment. 
Within Australia, stormwater reuse is being promoted as one way to lessen the demand on drinking water supplies for non-potable uses. Water reuse and recycling project must be of suitable quality or "fit for purpose", however when dealing with stormwater this presents many challenges due to the variability in quality. Modeling tools such as MUSIC provide a mechanism though which engineers can estimate the efficiency of their designs through specific monitoring of constructed projects is needed to provide greater certainty to land mangers, designers and the community.

The community's acceptability towards WSUD projects and their understanding of the limitations of designs to treat water to potable standard will take time and must be a consideration in the planning and promotion of such project. Facilitating this to some degree in Australia is the current drought and subsequent water restrictions that is raising the understanding and value of water as a limited resource. How this influences risk in the context of public health remains unknown though must be a primary consideration for designers and managers if acceptability and confidence of such schemes is to gain a permanent foothold within the engineering, park management and community physic.

From an integrated water management perspective projects such as the ones presented in this case study should be designed and promoted as having multiple benefits through managing the discharge and improving the quality from low frequent storms at the local scale, providing broader water conservation gains across the urban area and importantly improving community facilities.

\section{REFERENCES}

[1] Australian Bureau of Statistics, 2006. 2006 Census Community Profile series Ku-ringgai (A) LGA 14500 Catalouge No. 2001.0.

[2] Australian Bureau of Statistics, 2006. 2006 Census Community Profile series Ku-ringgai (A) LGA 14500 Catalouge No. 2001.0 Table B01.

[3] Jonasson, O. J., Davies, P., 2007. Stomwater management - Water balance modelling and impact on project costs - A case study from Ku-ring-gai Council, NSW. Proceedings of Ozwater 2007 March 2007.

[4] Booth, D. B., Jackson C. R., 1997. Urbanisation of aquatic systems - degradation thresholds, stormwater detention, and the limits of mitigation. Journal of the American Water Resources Association 33 pp. 1077-1090.

[5] Walsh, C.J., 2004. Protection of in-stream biota from urban impacts: to minimise catchment imperviousness or to improve drainage design? Marine and Freshwater Research 55 pp. 317- 326.

[6] Ladson, A.R. Walsh, C.J. Fletcher, T.D. Cornish, S. \& Horton, P., 2004. Improving stream health by reducing the connection between impervious surfaces and waterways Proceedings of the 3rd National Conference on Water Sensitive Urban Design. Engineers Australia and the Australian Water Association, Adelaide, SA. pp. 246257.

[7] Wright, I. A., Davies, P., Wilks, D., Findlay, Seand Taylor, M.P., 2007. Aquatic macroinvertebrates in urban streams: comparing ecosystem health in natural reference streams and urban streams. Proceedings from the 5th Australian stream management conference, Albury, NSW 21-25 May 2007 pp. 467 - 472.

[8] Institution of Engineers Australia, 2005. Australia Runoff Quality. Published by the Institution of Engineers Australia, Sydney Australia. 
[9] NSW Department of Environment and Conservation, 1996. Managing Urban Stormwater: Strategic Framework - Draft. NSW Government 1996 Sydney Australia.

[10] NSW Department of Environment and Conservation, 1997. Managing Urban Stormwater: Council Handbook - Draft. NSW Government November 1997 Sydney Australia.

[11] NSW Department of Environment and Conservation, 1999. Managing Urban Stormwater: Source Control - Draft. NSW Government January 1999 Sydney Australia.

[12] NSW Department of Environment and Conservation, 2004. Managing Urban Stormwater - stream remediation (Guidelines for Coastal NSW) - Draft NSW Government June 2004 Sydney Australia.

[13] NSW Department of Environment and Conservation, 2006. Managing Urban Stormwater - harvesting and reuse. NSW Government December 2006 Sydney Australia.

[14] NSW Department of Infrastructure, Planning and Natural Resources, 2005. Floodplain Development Manual - the management of flood liable lands. NSW Government December 2006 Sydney Australia.

[15] Institution of Engineers Australia, 1997. Australian Rainfall and Runoff - a guide to flow estimation 4th edition. Published by the Institution of Engineers Australia, Sydney Australia.

[16] BASIX SEPP, 2004. State Environmental Planning Policy-Building Sustainability Index (BASIX) NSW Government 2004 Sydney Australia.

[17] NSW Government, 2006. 2006 Metropolitan Water Plan. NSW Government 2006 Sydney Australia.

[18] Hatt, B. E., Deletic. A., and Fletcher. T D., 2006. Integrated treatment and recycling of stormwater: a review of Australian practice. Journal of Environmental Management 79 pp. 102-113.

[19] NSW Environment Protection Authority 1997. Managing Urban Stormwater: Treatment techniques - Draft. NSW Government 1997 Sydney Australia.

[20] http://www.environment.nsw.gov.au/mao/stormwater.htm, accessed 25th September 2007.

[21] CRC for Catchment Hydrology, 2005. MUSIC Used manual. CRC for Catchment Hydrology Melbourne, Australia.

[22] Australian and New Zealand Environment and Conservation Council and Agriculture and Resource Management Council of Australia and New Zealand, 2000. Australian Water Quality Guidelines for Fresh and Marine Waters, National Water Quality Management Strategy, Published by Australian and New Zealand Environment and Conservation Council, Canberra Australia. 